\title{
EDITORIAL
}

\section{Double Standards in Peacekeeping? Subcontracting Peacekeeping and International Humanitarian Law}

Keywords: ECOMOG; international humanitarian law; peacekeeping; United Nations.

\begin{abstract}
Increasingly the UN is 'subcontracting' peacekeeping and peace enforcement operations. The ECOMOG intervention in Sierra Leone is an example. Some members of ECOMOG have been accused of violating international humanitarian law. These accusations have not been adequately addressed by ECOMOG nor by the UN. The limited attention paid to this problem by the UN in 'subcontracted' operations contrasts with increased concern with respect for international humanitarian law by forces under UN command and control. It is argued that the UN should ensure that 'subcontracting' does not lead to lowering standards of international humanitarian law.
\end{abstract}

It is a truism to say that armed conflict is an important feature of our world. Numerous conflicts are taking place. Many of them have resulted in harrowing human suffering. There is every reason to expect that these events will continue to take place in the future. The international community has proven incapable of preventing or resolving a large number of conflicts. At the end of 1999 two reports were published by the United Nations concluding that the international community had failed to adequately respond to the attack on Srebrenica in July 1995 and the Rwandan genocide in 1994.

Despite this, there were some small rays of hope in 1999. On 7 July 1999 President Ahmad Tejan Kabbah of Sierra Leone stated that: "[t]oday, Sierra Leoneans have every reason to sing and shout for joy." He was referring to the peace agreement signed that day between the government of Sierra Leone and the rebel movement Revolutionary United Front (RUF). The peace agreement is a comprehensive document. It provides for a cessation of hostilities, a transitional government, disarmament and other security measures, and a commission to implement the most important provisions of the agreement. With respect to human rights and international humanitarian law, the agreement contains a provision granting amnesty as well as a provision on a Truth and Reconciliation Commission.

The peace agreement has until now succeeded in bringing to an end the civil war in Sierra Leone. The civil war started in 1991 when the RUF movement entered the country from Liberia. In the following years the RUF had some military success but was unable to defeat the government. A complex situation 
developed as other parties became involved in the conflict. These included the Kamajors, originally a rural militia, and the private security firm Executive Outcomes hired by the government. Another force that became involved was a multinational intervention force, the Economic Community Monitoring Group (ECOMOG), which was established by the Economic Community of West African States (ECOWAS). This force was comprised largely of Nigerian troops but also included other West African troops operating under the auspices of ECOWAS. ECOMOG had been present in Sierra Leone since 1990, first as a base of operations to Liberia and later supporting the Sierra Leone government. In 1998 the force ousted the RUF and its allies from the capital Freetown that had been under rebel control since a coup several months earlier. After the signing of the Sierra Leone peace agreement the Nigerian government indicated that it would start withdrawing its forces from ECOMOG. Nevertheless, it appears that a number of troops will remain in Sierra Leone. ECOWAS has adopted a new mandate for these troops, including maintaining peace and security, providing protection for the United Nations operation, and cooperating in disarmament and demobilization and distributing humanitarian relief.

The conflict in Sierra Leone has been characterized by widespread violations of human rights and international humanitarian law. The rebels adopted terror as a tactic. To discourage civilians from supporting the government they killed, raped, mistreated and abducted civilians accused of being government supporters. The rebels regarded the civilian population as a military target. Their particular trademark was the systematic cutting off of limbs, mutilating thousands. Other parties in the conflict were also reported to have committed violations of human rights. Government forces carried out summary executions and mistreated detained persons. ECOMOG was also accused of violations of human rights and international humanitarian law. Human rights organizations reported numerous executions of rebel prisoners and suspected collaborators without investigation or trial. In addition, ECOMOG was alleged to have failed to distinguish between military objectives and civilians by firing at human shields being used by the rebels. Following these reports the United Nations expressed its concern about ECOMOG's respect for human rights.

Within ECOMOG an internal mechanism is set up for the investigation of violations of international humanitarian law. There have been few investigations undertaken with respect to the allegations of summary executions, however. In April 1999 the ECOMOG commander established a Civil/Military Relations Committee. The initial membership of the Committee included representatives from the Sierra Leone parliament, police, media, bar association, United Nations, the government of Sierra Leone, civil society and ECOMOG. The precise terms of reference for this Committee are unclear. According to ECOMOG, the purpose of the Committee is to ensure a good relationship between the civil populace and ECOMOG personnel. It assures that normal military procedures for handling issues related to international humanitarian law are sufficient 
should the need arise. Other sources state that the purpose of the Committee is to investigate violations of international humanitarian law by ECOMOG and other security agencies. Every citizen in any ECOMOG area of operation can file a complaint with the Committee. A Sub-committee then investigates the complaint after which the entire Committee makes a recommendation to the relevant authorities (the police, defense headquarters, the Attorney-General's Office and ECOMOG High Command) of the appropriate action to remedy, correct or reverse the act complained of. Importantly, the Committee's mandate does not extend to incidents prior to 1 April 1999 when most executions are alleged to have taken place. So far the Committee has recommended a few sanctions.

The United Nations has supported the ECOMOG intervention in Sierra Leone. After the coup the Security Council imposed an embargo on the rebels and authorized ECOMOG to implement the embargo. After ECOMOG ousted the rebels from the capital the Council commended ECOMOG "on the important role they are playing in support of the objectives related to the restoration of peace and security." The Council also urged member states to provide technical and logistical support to ECOMOG. After the peace agreement was signed the Council welcomed the steps taken by ECOMOG towards its implementation.

United Nations support for ECOMOG is part of a trend towards 'subcontracting' peace operations. In the last decade, after initial optimism, it has become clear that it is impossible to respond to all conflicts with UN peacekeeping operations. The reasons for this include political disagreement in the Security Council, the inability of the UN to organize and control large military operations and the unwillingness of member states to contribute financially to these operations. This has led to what has been called the "crisis in peacekeeping". crisis was canvassed by the operation in Somalia in 1995 that was regarded as a complete failure. After this operation, member states became very wary of crossing the "Mogadishu line."

As a response to UN passiveness interventions have been increasingly carried out by members states individually, acting as a coalition or in a regional organization and authorized by the United Nations. This trend started with operation Desert Storm in 1991, an operation authorized by the Security Council but carried out under the control of the United States. Since then peacekeeping or peace enforcement has been 'subcontracted" ${ }^{2}$ by the UN in, amongst other states, Somalia, Haiti, Albania, the Central African Republic, Rwanda, and Zaire.

Subcontracting peacekeeping and peace enforcement has the advantage of providing a possibility to respond to conflicts that the Security Council is unable or unwilling to address itself. The Security Council was unwilling to send UN peacekeepers to Sierra Leone but was content to let ECOMOG restore peace.

1. A. Roberts, The Crisis in UN Peacekeeping, 36 Survival 93 (1994).

2. M. Griffin, Blue Helmet Blues: Assessing the trend Towards 'Subcontracting' UN Peace Operations, 30 Security Dialogue 43 (1999). 
The clear disadvantage of subcontracting is that the Security Council delegates control over the operation to states or regional organizations. Subcontracting erodes the Council's primary responsibility for and authority over multilateral peace operations.

An important consequence is that it becomes difficult for the UN to ensure that multilateral operations meet $\mathrm{UN}$ standards of international humanitarian law. The Organization has been increasingly concerned with ensuring respect for international humanitarian law by United Nations peacekeeping and peace enforcement operations. The UN Commission on Human Rights has expressed its concern over the conduct of UN personnel. In August 1999 a SecretaryGeneral's Bulletin on Observance by United Nations forces of international humanitarian law was issued. ${ }^{3}$ This document sets out fundamental principles and rules of international humanitarian law applicable to United Nations forces conducting operations under United Nations command and control. In addition, the United Nations Secretariat has started tracking individual cases of misconduct and inquiring about follow-up actions at the national level.

In subcontracted operations, there appears to be less concern about monitoring respect for international humanitarian law. The United Nations has expressed concern about reports of summary executions committed by ECOMOG, but it has not insisted on adequate responses to these reports. Having regard to the serious allegations against ECOMOG, a few internal investigations and a Civil/Military Relations Committee with a very limited mandate are not an adequate response. Summary executions constitute grave breaches of the $1949 \mathrm{Ge}-$ neva Conventions. States parties including the states contributing troops to ECOMOG are under an obligation to search for persons alleged to have committed such grave breaches and to bring them before their courts or extradite them. In the case of ECOMOG this obligation has been neglected.

The discrepancy between the attention for respect for international humanitarian law by operations under United Nations command, and 'subcontracted' operations like ECOMOG, is of serious concern. Subcontracted operations acting in the name of the United Nations should respect the same standards as operations under United Nations command. Clearly the United Nations has decided that there are minimum standards for forces acting in its name. The Security Council should insist that these rules be respected before authorizing a particular operation. If these rules are not respected after an authorization the United Nations should take appropriate action, ranging from diplomatic steps to revoking its authorization. The inability of the United Nations to address a conflict without the help of subcontractors should not lead to lowering standards of international humanitarian law. Putting an end to violations of humanitarian law is often precisely one of the underlying purposes for authorizing intervention by

3. Secretary-General's Bulletin, Observance by United Nations Forces of International Humanitarian Law of 6 August 1999, UN Doc. St/SGB/1999/13. 
the Security Council. It would be bizarre if this were achieved through committing violations of international humanitarian law.

Subcontracting is here to stay. The most recent example is the multinational operation in East Timor (INTERFET). Another is the new mandate for ECOMOG in Sierra Leone. It is important that the United Nations shows more concern about respect for international humanitarian law by such operations. There are potentially a large number of victims of international humanitarian law violations that are committed under the auspices of the United Nations. A starting point could be to insist that perpetrators of violations of international humanitarian law in ECOMOG are held accountable. The United Nations has stated that perpetrators of war crimes, crimes against humanity and serious violations of human rights should not profit from the amnesty provided for in the Sierra Leone peace agreement. This principle should also apply to ECOMOG.

Marten Zwanenburg 